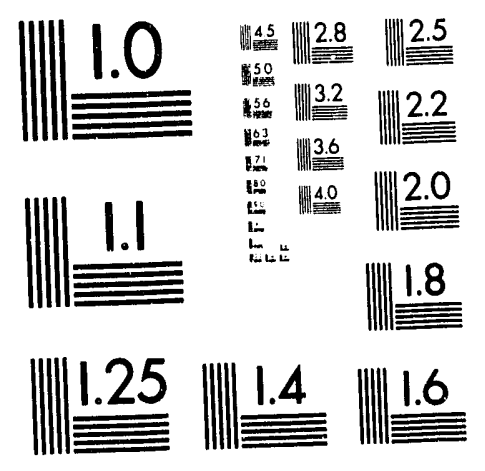



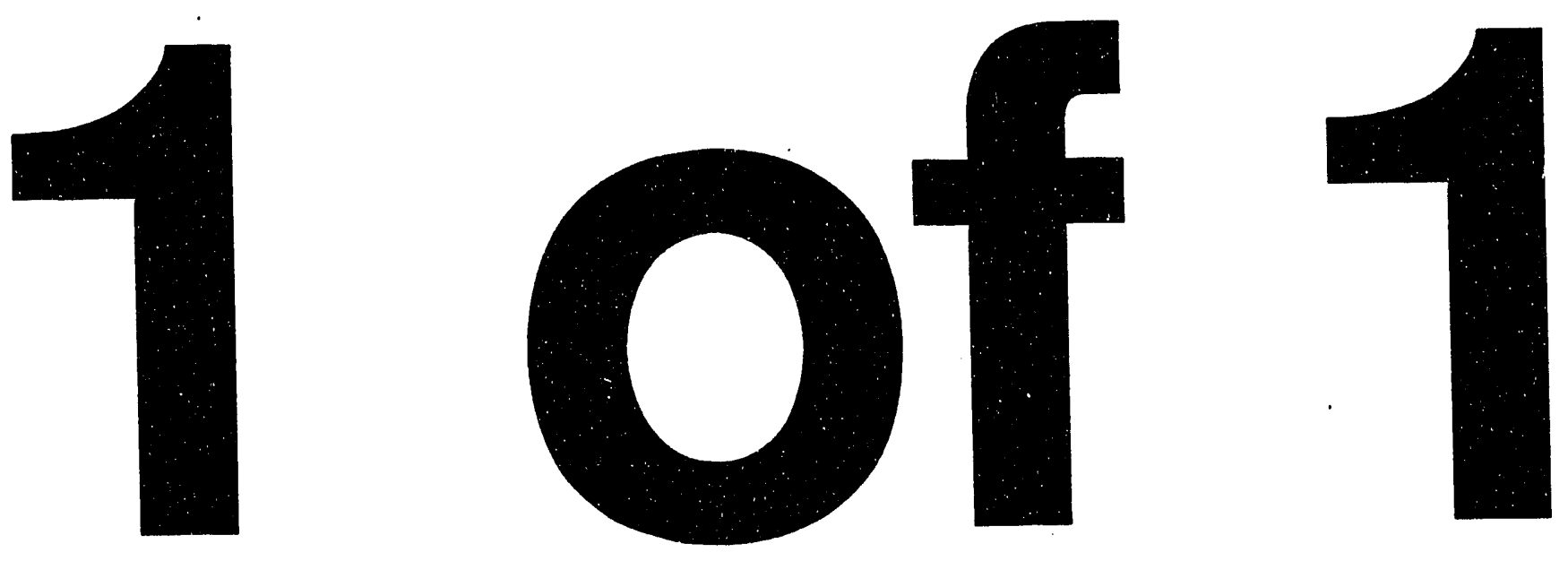
DOE/EA-0824

\section{CURECANTI-BLUE MESA-SALIDA 115-KV TRANSMISSION LINES ACCESS ROADS REHABILITATION, MAINTENANCE, AND CONSTRUCTION PROJECT}

\section{DRAFT}

\section{ENVIRONMENTAL ASSESSMENT}




\section{TABLE OF CONTENTS}

1. Introduction and Background .................

2. Purpose and Need ..................... 9

3. Proposed Project and Alternatives . . . . . . . . . . . . 11

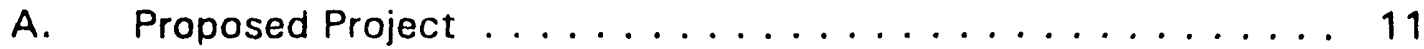

B. Alternatives to Proposed Action ............... 23

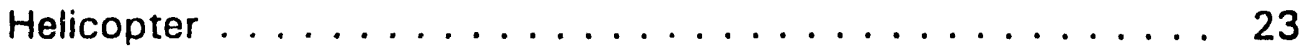

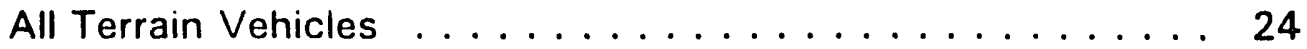

No action ........................ 24

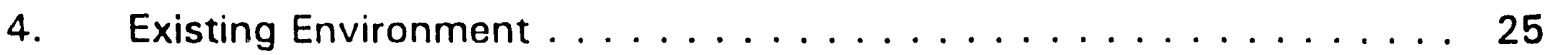

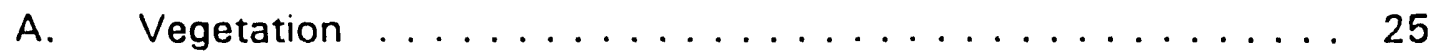

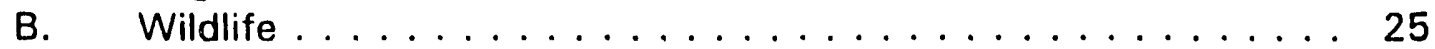

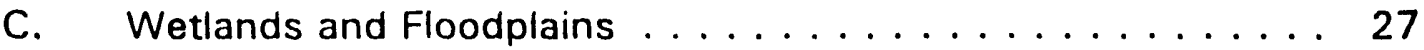

D. Special Status Plant or Animal Species . . . . . . . . . . . . 27

E. Cultural Resources ..................... 28

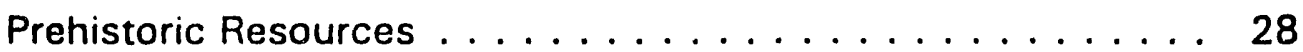

Historic Resources ................... 31

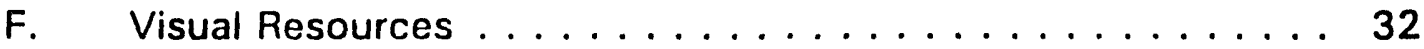

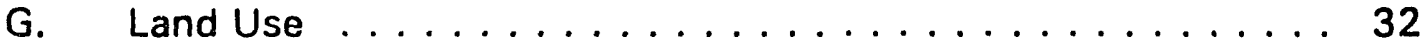

5. Environmental Consequences ................. 33

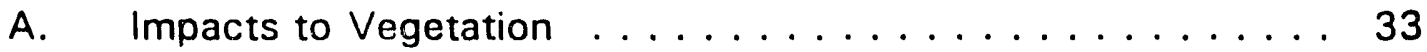

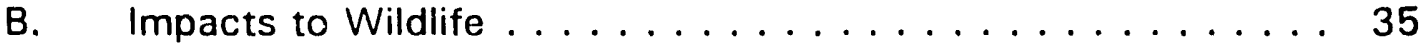

C. Impacts to Wetlands and Floodplains ............. 37

D. Impacts to Special Status Plant or Animal Species . . . . . . . 37

E. Impacts to Cultural Resources ................ 38

F. Impacts to Visual Resources .................. 39

G. Impacts to Land Use ..................... 40

H. Other Potential Impacts .................. 42

6. Compliance With Other Environmental Regulations . . . . . . . 42

7. Agencies and Persons Consulted .................43

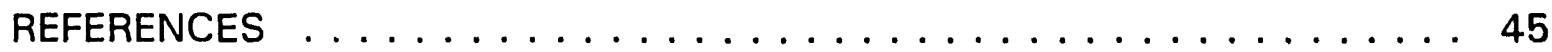




\section{LIST OF FIGURES}

Figure 1.a-e Approximate locations of the Curecanti-Blue Mesa-

Salida $115-k V$ transmission lines and associated

substations ....................... 3-7

Figure 2. Typical water crossing ................... 14

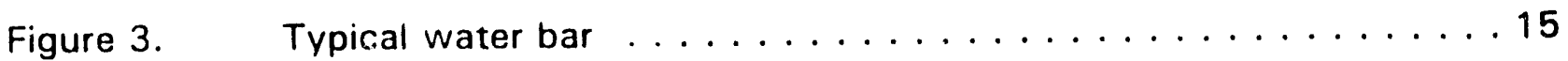

Figure 4.a-c Existing and proposed Blue Mesa-Salida 115-kV

transmission line access roads within Gunnison

National Forest and adjacent Bureau of Land

Management, State of Colorado, and private lands ..... 17-19

Figure $5 . \quad$ Proposed access road relocation $\ldots \ldots \ldots \ldots \ldots \ldots \ldots \ldots \ldots \ldots \ldots \ldots$

Figure 6. Access road proposed for construction ............. 22 


\section{Introduction and Background}

Western Area Power Administration (Western) is a power marketing agency of the U.S. Department of Energy, with jurisdiction in 15 western states. The Salt Lake City Area (SLCA) of Western performs the agency's mission in parts of Colorado, New Mexico, Texas, Utah, Arizona, Wyoming, and Nevada. As part of its mission, Western owns, operates, and maintains a system of transmission lines for transmitting bulk electrical energy from points of generation to and between delivery points. Part of that system in southwestern Colorado includes the Blue Mesa-Curecanti and Blue Mesa-Salida 115-kV transmission lines. Western proposes to conduct maintenance and improve its access roads for these two transmission lines.

The Curecanti Substation is located near Cimarron, Colorado, in Section 9, T48N, R6W, in Montrose County. The Blue Mesa Switchyard is located near the Blue Mesa Powerplant in Section 5, T48N, R4W, in Gunnison County. The Salida Substation is located near Poncha Springs, Colorado, in Section 9, T49N, R8E, in Chaffee County. These facilities are electrically interconnected by 115-kilovolt ( $k V$ ) transmission lines. The Blue Mesa-Salida $115-k V$ transmission line is tapped at the Skito Tap, Gunnison, and North Main Substations. The elevation of the lands traversed by the transmission lines ranges from about 7,200 feet above mean sea level at the Curecanti Substation to just under 11,000 feet near Monarch Pass. On the west side of Monarch Pass, the transmission lines are in the Gunnison Basin and roughly follow the Agate Creek, Tomichi Creek, and Gunnison River drainages. On the east side of the pass, the 
Blue Mesa-Salida transmission line is in the Arkansas Basin and roughly follows the Fosses Creek, East Arkansas River, and Arkansas River drainages. The transmission lines and access roads are located on private, state of Colorado, Curecanti National Recreation Area (CNRA), Bureau of Land Management (BLM), and U.S. Forest Service (USFS) lands. Western has easements for the transmission lines that provide for access but not all of the access roads are specifically described in the easements. The substations are located on lands owned by Western. The approximate locations of these electrical transmission facilities are indicated on Figures $1 \mathrm{a}-\mathrm{e}$.

In 1952, the U.S. Bureau of Reclamation completed construction on the Gunnison-Salida portion of the Blue Mesa-Salida transmission line. The remainder of the two transmission lines was completed in 1964. Both the Blue Mesa-Curecanti and Blue Mesa-Salida transmission lines are wood-pole $\mathrm{H}$-frame construction. In 1989/90, Western conducted a wood-pole inspection and treatment program for the transmission lines. During that inspection 268 poles were found to be decayed or damaged beyond repair. At that time, inadequacies in access to portions of the transmission line were documented.

As part of its routine maintenance, Western uses a helicopter to conduct aerial patrols of each transmission line three to four times each year. Ground inspections are conducted on each transmission line at least once each year. During the ground inspections, regular maintenance, such as tightening hardware and replacing worn or damaged parts, is performed. Nonroutine maintenance 


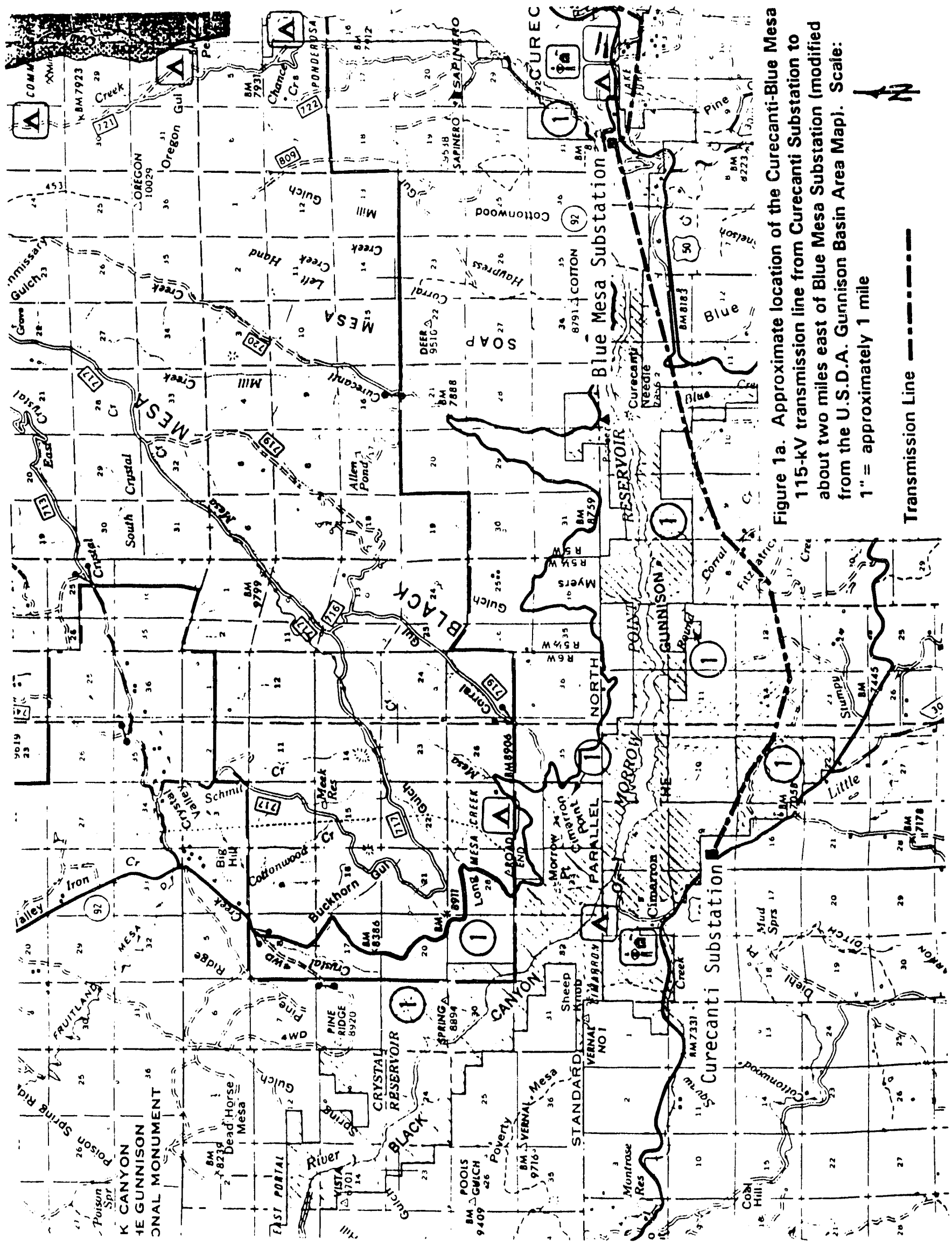




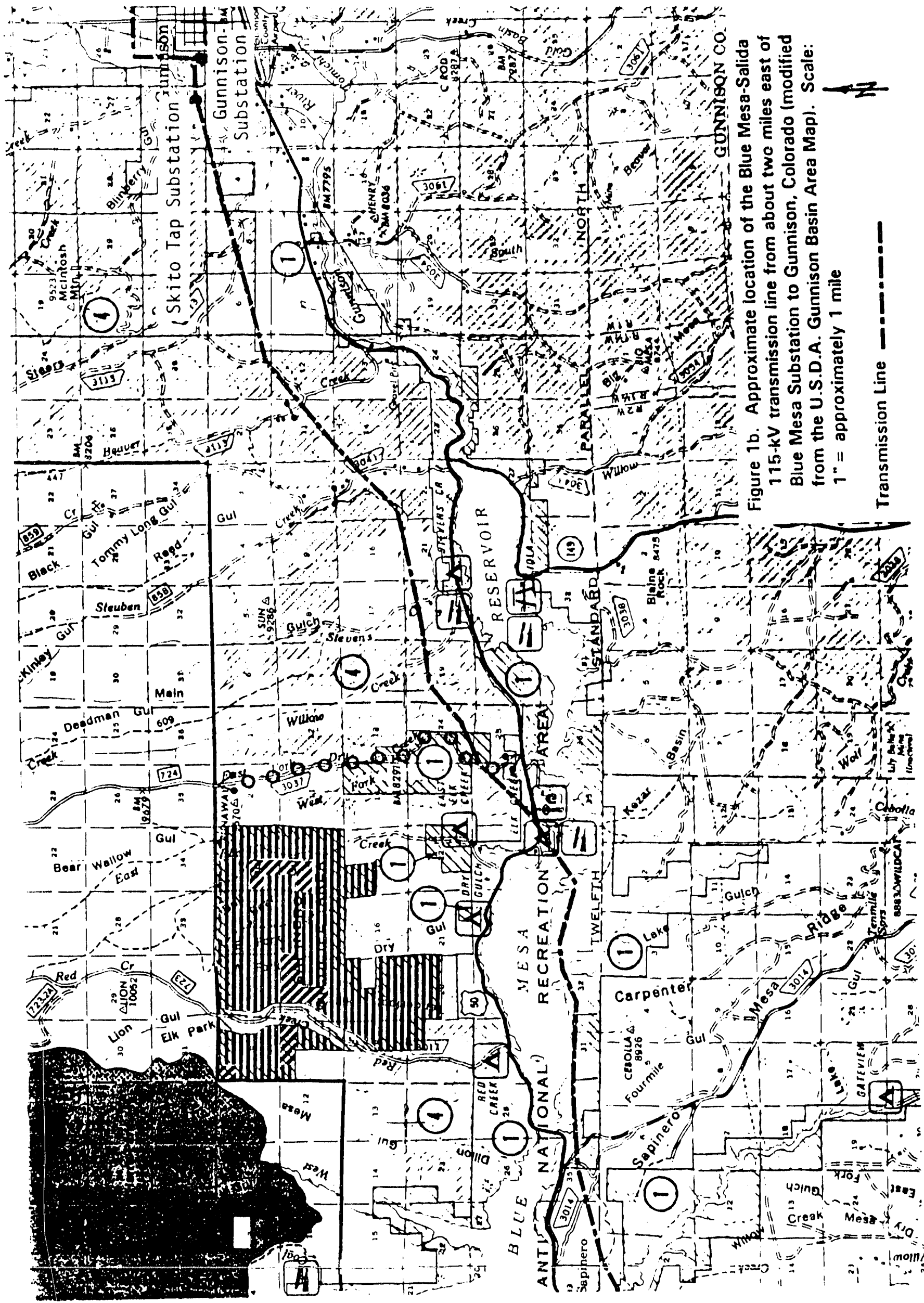




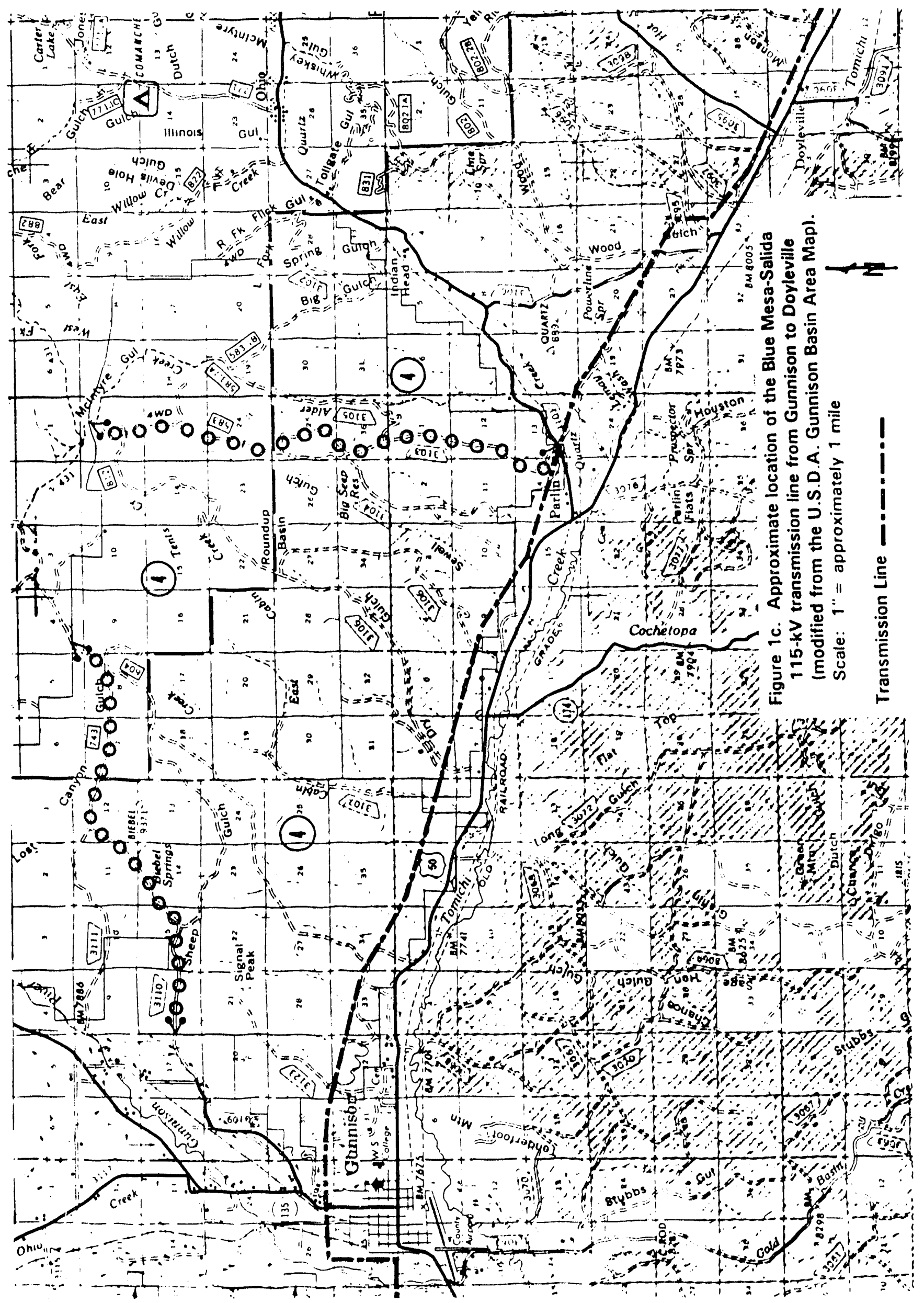




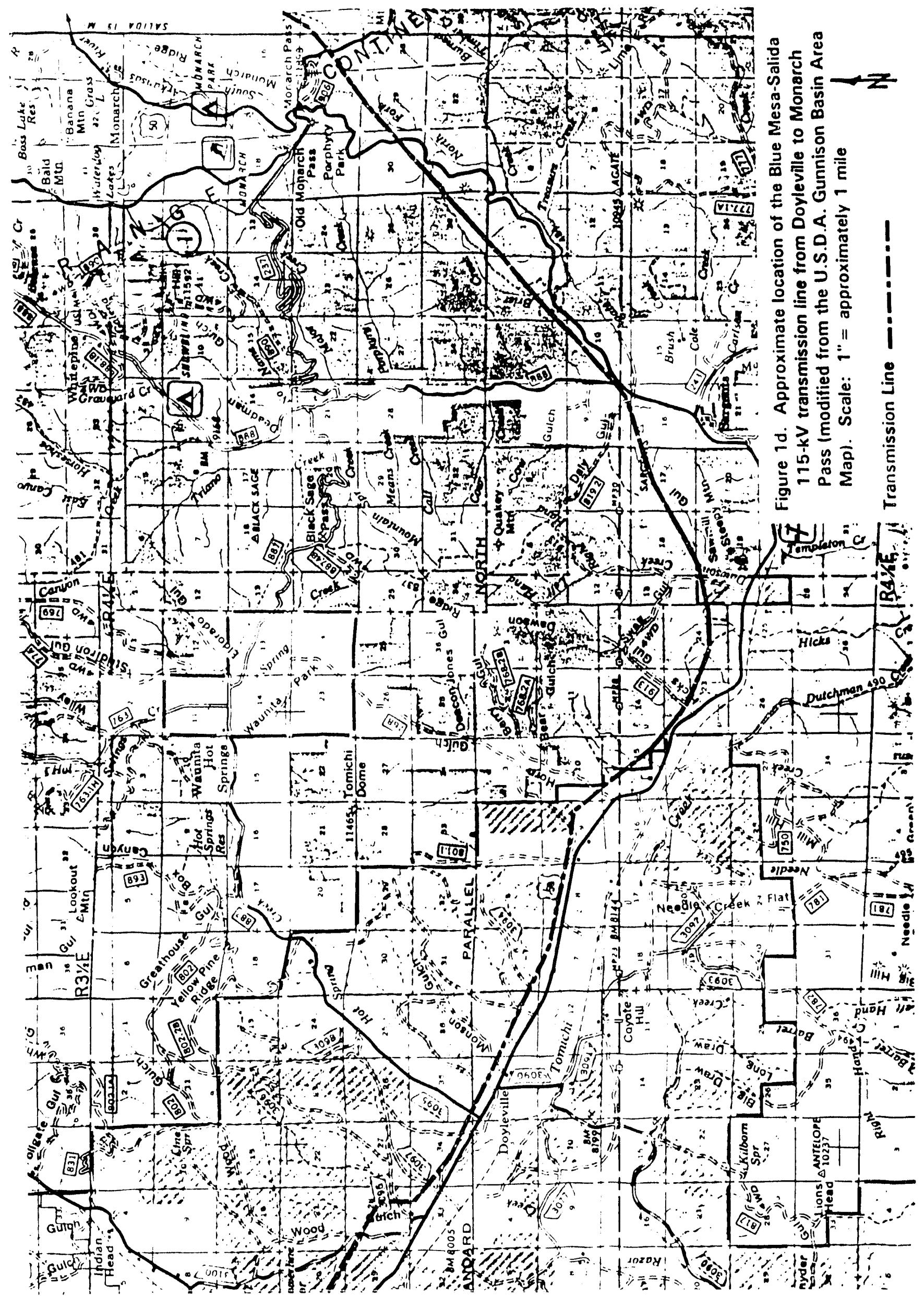




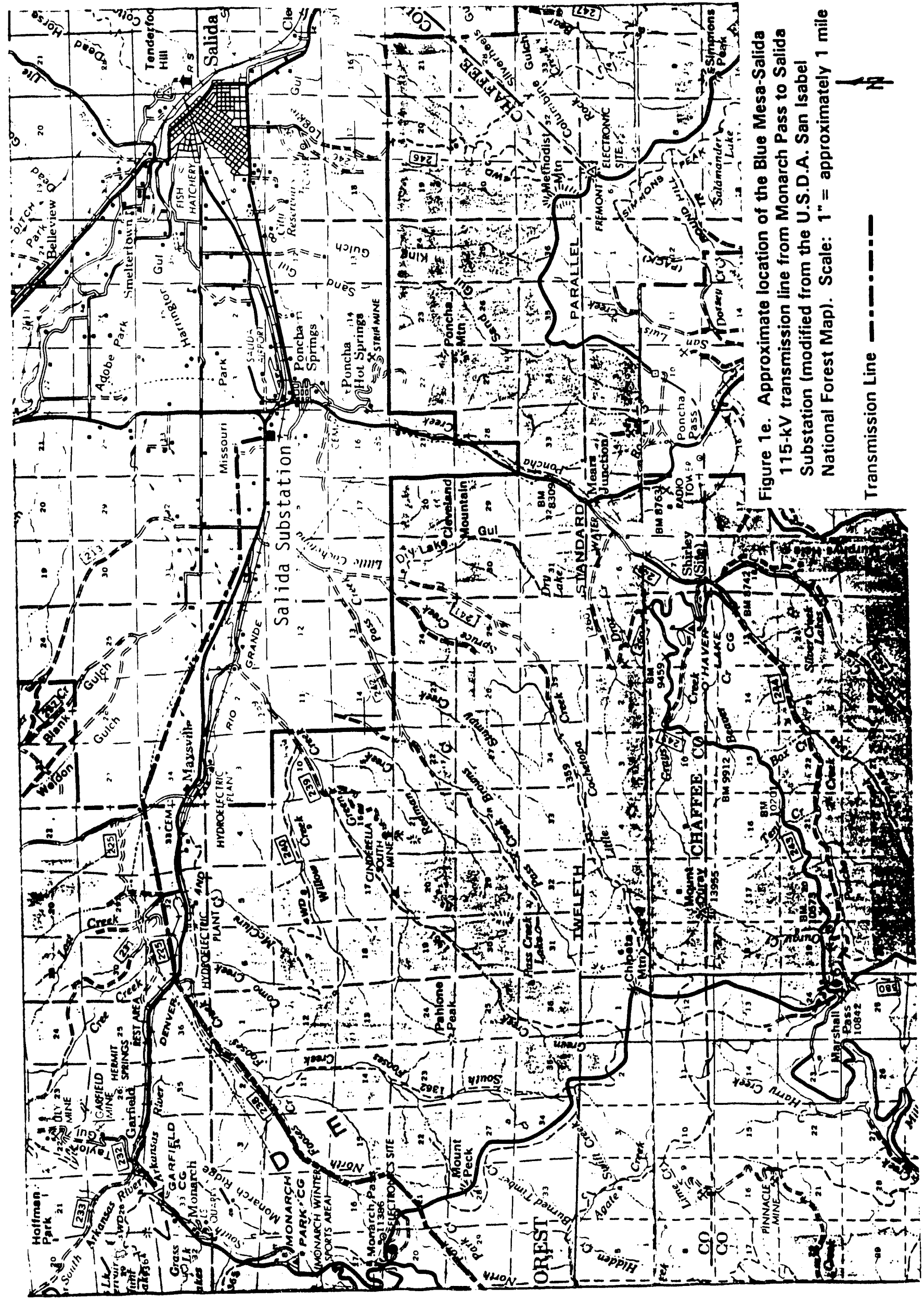


includes such activities as replacing decayed or damaged poles or crossarms, and repairing damaged insulators, conductors and ground wires. Emergency maintenance includes any activity required to restore service following an unplanned outage of the transmission line.

Traditionally, working on high voltage transmission lines has been viewed as an inherently dangerous activity. However, the safety of Western and contractor personnel and the general public is a major goal of the agency. Western is constantly seeking to improve the conditions under which its employees work to provide a safe and healthful environment. Adequate access to transmission line facilities has an important role in the provision of a safe working environment. Most accidents occur when the worker experiences a lack of concentration or a piece of equipment fails to function properly or breaks. It is therefore important to ensure that line crews are not unduly stressed, either physically or emotionally, prior to actually beginning work on transmission facilities. In addition, it is important that line crews have appropriate tools and equipment and that they are in good condition. Among the tools that are required from time to time in maintaining a transmission line are "hot sticks," wrenches, screwdrivers, hammers, prybars, etc.; equipment includes utility trucks, cranes, aerial manlifts, climbing belts and hooks, and assorted items of hardware. The size of some of vehicular equipment is considerable and adequate vehicular access to each transmission structure is important for providing safe working conditions. 
SLCA's aerial manlift vehicle is a Hi Ranger Model 10-90-1, which weighs 41,000 pounds, is 8 feet wide with an overall length of about 50 feet with 14 feet of front overhang and 3-1/2 feet of rear overhang for the boom, when folded. This vehicle has a vertical reach of about 95 feet. It requires a minimum turning radius of about 20 feet. SLCA's crane is a Pettibone 80 TK-LS Truck Krane. It is 8 feet wide, 45 feet long overall and weighs 77,000 pounds. It requires a minimum turning radius of 38 to 40 feet. Because of its low ground clearance and heavy axle weight, the crane requires fairly good roads. On poorer roads, the crane must be towed with a bulldozer.

Perhaps the most critical tools used by linemen are "hot sticks." Hot sticks are specially manufactured, highly insulated tools that are used to work on energized electrical facilities. In order for them to maintain their dielectric qualities and thus their capability of protecting the user from injuries and death from electrical shock, they are cleaned and inspected regularly. Any defect in a hot stick could provide an opportunity for an electrical current to pass through or flash over to the lineman and therefore is reason for rejection of the tool. In order to protect them from damage, hot sticks are carried in special trailers where they are "cradled" in padded brackets in a dust-free environment.

\section{Purpose and Need}

The purpose of and need for the proposed action is to provide adequate access to the Curecanti-Blue Mesa-Salida transmission lines so that required mainte- 
nance can be performed. Adequately and safely maintaining the Curecanti-Blue Mesa-Salida transmission lines requires the ability to access each structure with various kinds of equipment. For routine maintenance, a four-wheel drive pickup truck with a utility body, towing a hot stick trailer, is necessary. Nonroutine maintenance, and even some routine maintenance, may require a truck with aerial manlift capability to reach the top of structures that are as tall as 90 feet; pole replacement requires a truck pulling a pole trailer with the pole, which can be as long as 90 to 100 feet, an auger truck, and a crane of sufficient size to handle the pole.

Because of the age of the Curecanti-Blue Mesa-Salida transmission lines, maintenance requirements are increasing and the access roads are in need of repair, particularly on the Gunnison-Salida portion. At the present time, a total of 29 wood poles out of the 268 poles that failed inspections are considered "danger poles." Danger poles are defined as individual poles of a structure that are so structurally unsound as to be unsafe to climb and are in danger of collapse under severe structural loading conditions. Those danger poles that are accessible have been or are in the process of being replaced.

In addition to keeping the lines in service, other concerns include the risk of fires if a structure were to fail and the conductors fall; a direct threat to humans and or animals due to electrocution from contact with a live conductor or other energized part of the transmission line if it only fell part-way to the ground; and erosion on the existing access roads. Western believes it is imperative that the 
danger poles be replaced as soon as possible and the access roads be maintained and improved where necessary.

Western is particularly concerned for the Gunnison-Salida portion of the Blue Mesa-Salida transmission line. This is the oldest section of the transmission line, consequently the portion with the most numerous and severe problems. Access problems on this portion of the transmission line are especially acute on the Gunnison National Forest, where seven danger poles have been identified and access to the transmission line is barely adequate and even nonexistent to some parts, including several of the danger poles.

\section{Proposed Project and Alternatives}

\section{A. Proposed Project}

Western proposes to rehabilitate or maintain its existing access roads for the Curecanti-Blue Mesa-Salida transmission lines; to construct new access roads where needed to provide adequate access; and to reroute a section of a road where the turn radius is too small for access by maintenance vehicles. The project would consist of a series of independent actions; if one maintenance or rehabilitation activity is performed at a location, it does not require or cause another activity to be performed at a different location.

The kinds of activities that may be performed at specific sites on the access roads include grading; installing, repairing, and/or cleaning water 
crossings, water bars, $v$-shaped ditches, and culverts; removing large vegetation and rocks from the roadway; and similar activities. Some of these activities are described in detail below:

(1) Grading utilizes a road grader with a blade or a small tracked bulldozer to scrape roadway surfaces to a uniform cross-section. The roadbed is graded to a smooth surface paying particular attention not to scar or excavate the banks or shoulders more than is necessary to accomplish the grading. Grading is implemented in areas where erosion and/or rutting caused by vehicle wheels has created depressions and cuts in the road, which are conducive to roadbed erosion.

(2) Pit run gravel may be installed in an area of saturated roadbed. The saturated area would be armored with 4-inch or smaller rock in 6 -inch layers and then covered by 6 inches of road base gravel which would then be compacted into the road surface. This forms a structural bridge, stabilizing the road and curtailing erosion.

(3) Where a small ephemeral drainage crosses the road, a water crossing may be installed to armor the road surface. Installing a water crossing consists of lowering slightly the bottom of the drainage and adjacent road surface where the drainage crosses the road and placing 4-inch to 12 -inch rock in the excavated area. This would allow the use of the road during or immediately after events when 
water is in the drainage and prevent erosion across the road. Without the water crossing, when water is in the drainage, use could be precluded or cause damage to the road and/or accelerate erosion. A typical water crossing is illustrated in Figure 2.

(4) In places where surface runoff flows along the road, water bars serve to direct the water off of the road surface, thus preventing erosion. Water bars have been used successfully by land management agencies like the USFS and BLM to control erosion on roads on public lands. A water bar consists of a wide shallow scale cut across the road at an angle of about 30 degrees to the direction of the road. The excavated soil is shaped into a low and wide linear berm paralleling the downhill side of the scale. The width of the water bar and depth of the excavation depends upon the steepness of the slope. A typical water bar is illustrated in Figure 3.

(5) Some drainages that cross the access roads are of sufficient size to require a pipe culvert, which usually consists of a corrugated metal pipe through which the drainage is allowed to flow under the road. Installation of a new culvert requires excavating a trench in the roadbed, placing bedding material in the trench, placing the CMP, and backfilling the trench. The backfill material is then compacted and the culvert covered. Cleaning culverts includes removing soil, silt, and debris from the inlets, outlets, and barrels. 


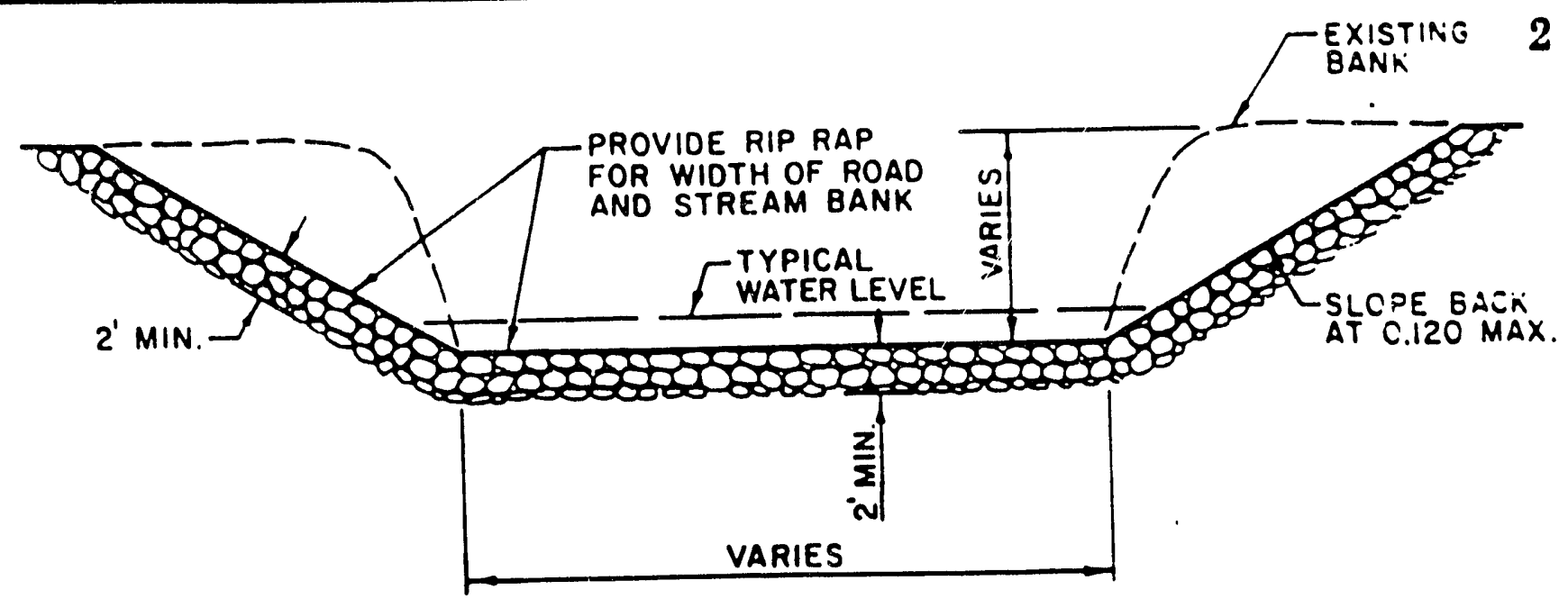

TYPICAL WATER CROSSING

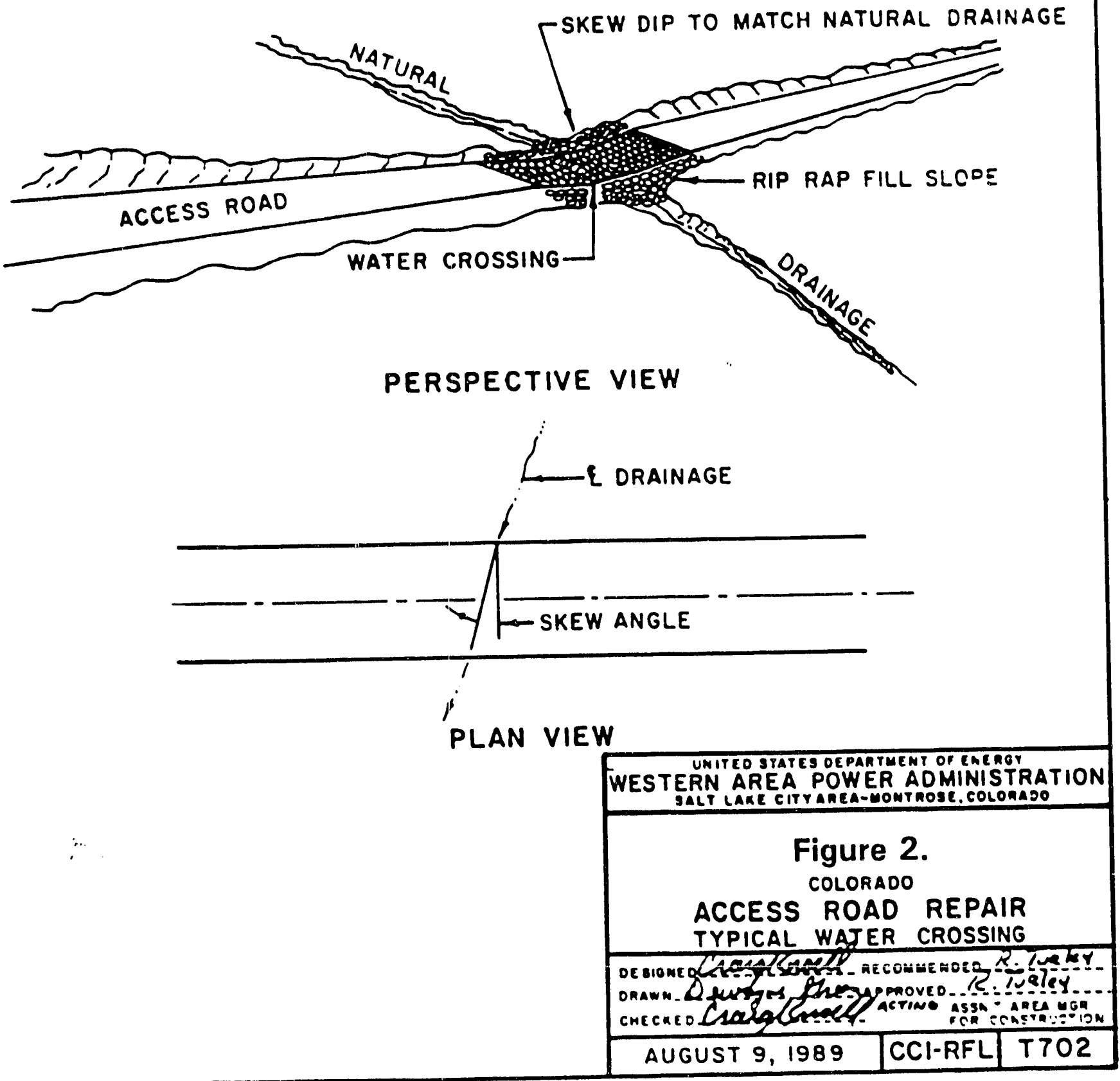



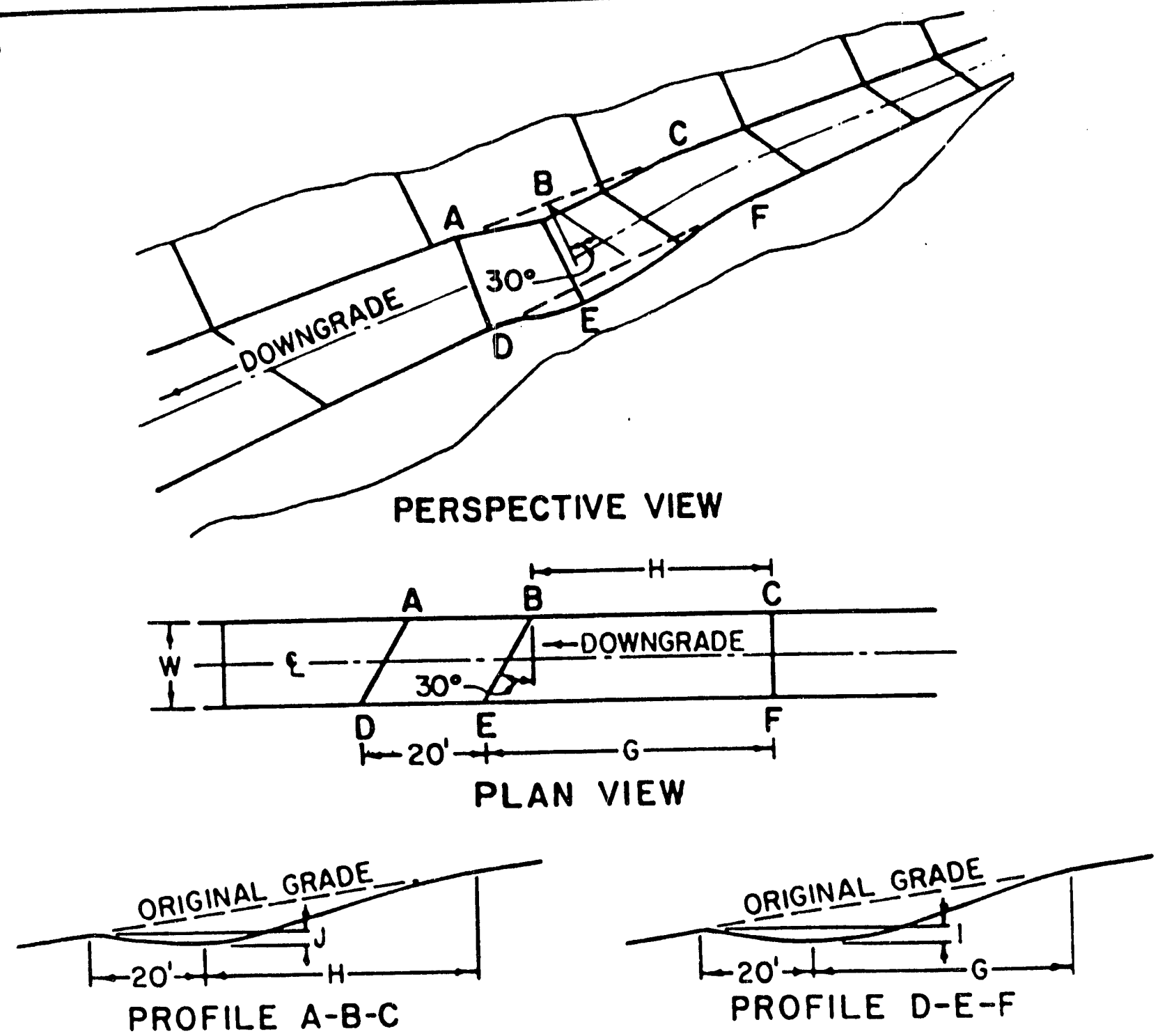

NOTES

I. WATER BAR OUTLETS WILL BE CONSTRUCTED

TO DRAIN FREELY AWAY FROM ROAD. ANY

OUTLET DITCHING REQUIRED TO ACCOMPLISH

THIS WILL BE CONSIDERED INCIDENTAL TO

CONSTRUCTION OF THE WATER BAR UNLESS

OTHERWISE SPECIFIED.

\begin{tabular}{|c|c|c|c|c|}
\hline \multirow{4}{*}{$\begin{array}{c}\text { ROAD } \\
\text { GRADE } \\
\text { IN } \\
\%\end{array}$} & \multicolumn{4}{|c|}{$30^{\circ}$ WATER BAR } \\
\hline & \multicolumn{4}{|c|}{ W 12} \\
\hline & \multicolumn{2}{|c|}{ LENGTH } & \multicolumn{2}{|c|}{ DEPTH } \\
\hline & G & $\mathrm{H}$ & 1 & J \\
\hline$<6$ & 57 & 50 & 1.00 & 0.50 \\
\hline 6 & 62 & 55 & 1.00 & 0.50 \\
\hline 7 & 67 & 60 & 1.10 & 0.50 \\
\hline 8 & 72 & 65 & 1.10 & 0.50 \\
\hline 9 & 77 & 70 & 1.10 & 0.50 \\
\hline 10 & 82 & 75 & 1.20 & 0.50 \\
\hline$>10$ & 100 & 90 & 130 & 0.50 \\
\hline
\end{tabular}

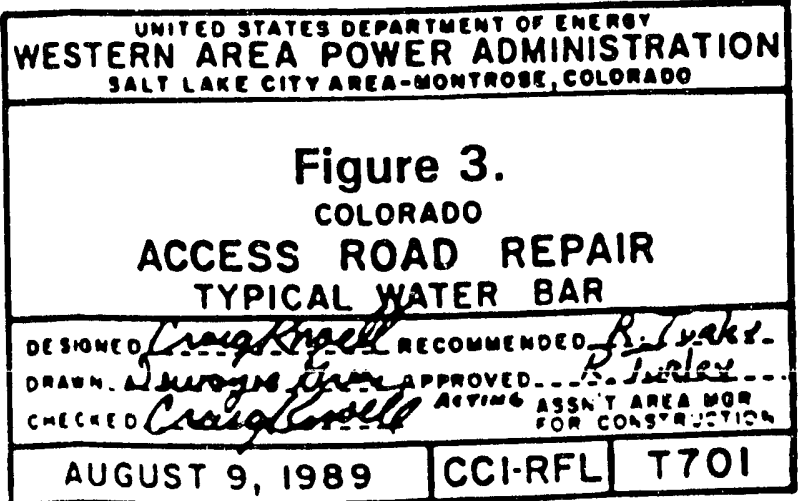


The precise locations for specific maintenance activities are not known at this time. They would be determined by field inspections by Western, in consultation with appropriate land management agencies. The maintenance activities would be confined to the already-developed roadways for the most part. It may be necessary for some work to be performed in areas immediately adjacent to the developed roadway (i.e., construction of new v-shaped ditches, placement of riprap at the end of a culvert, etc.l; however, such activities would be expected to disturb less than 1 acre of land throughout the length of the access roads.

Western also proposes to construct several new roads, or portions of roads in order to improve access or attain access to heretofore unaccessible structures and sections of the transmission lines. On Gunnison National Forest, a total of about 3.4 miles of new access roads would be constructed and about 3 miles of existing access roads would be abandoned by Western under the proposal. The approximate locations on Gunnison National Forest of the existing roads and proposed new roads, are illustrated in Figures 4 a-c. Western would consult with the USFS regarding the disposition of the abandoned roads. Abandoned roads that are not required for public access may be reclaimed. 


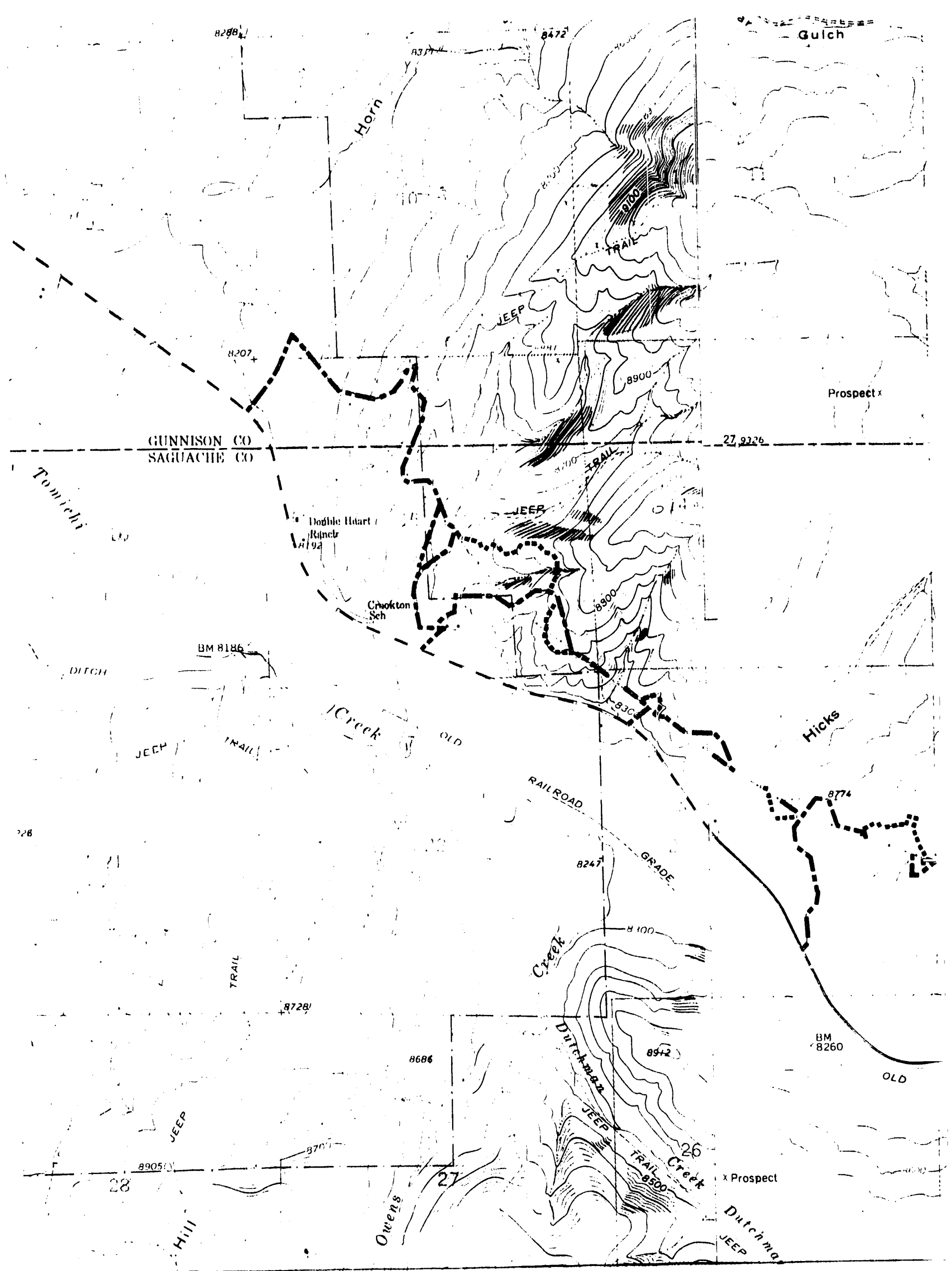




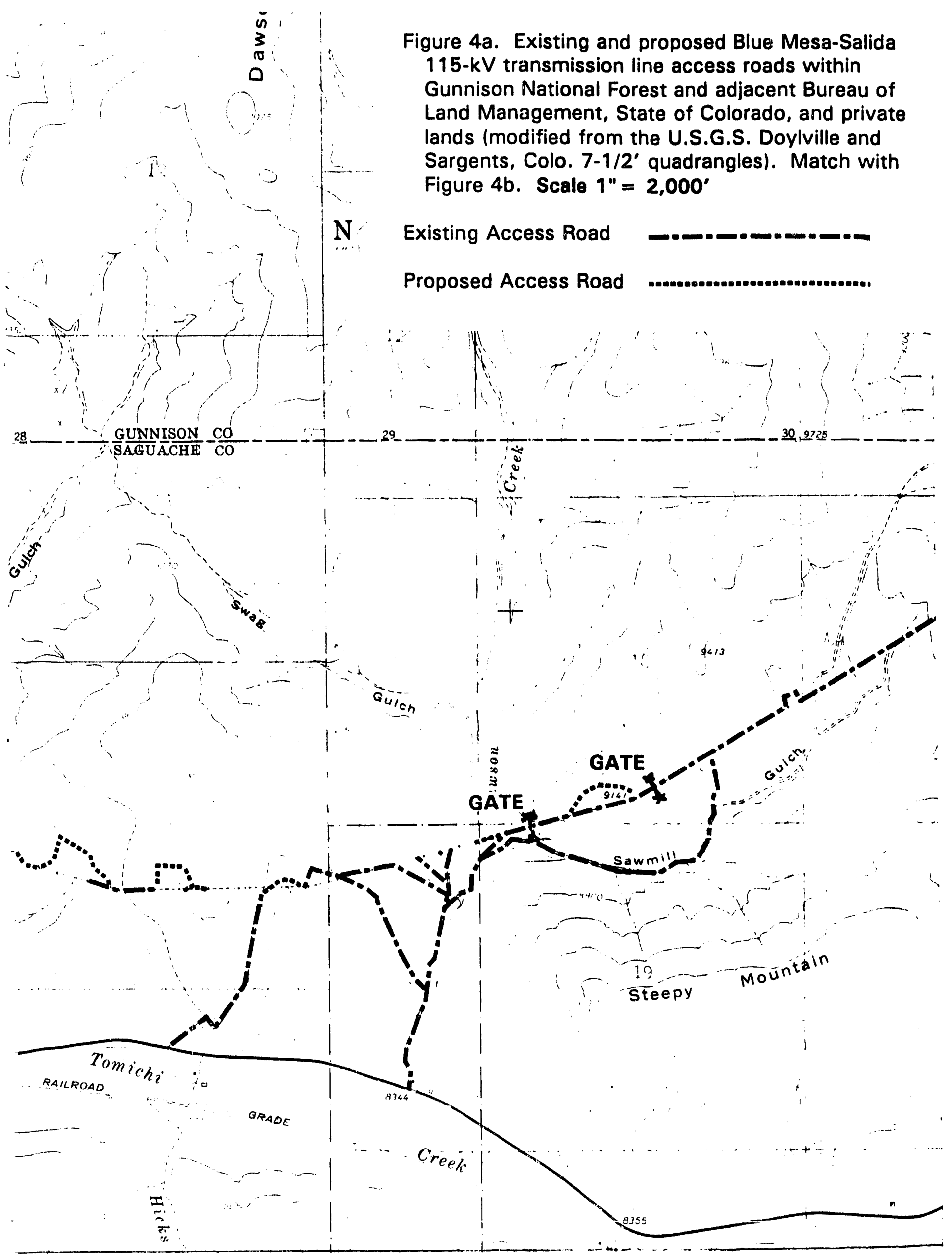




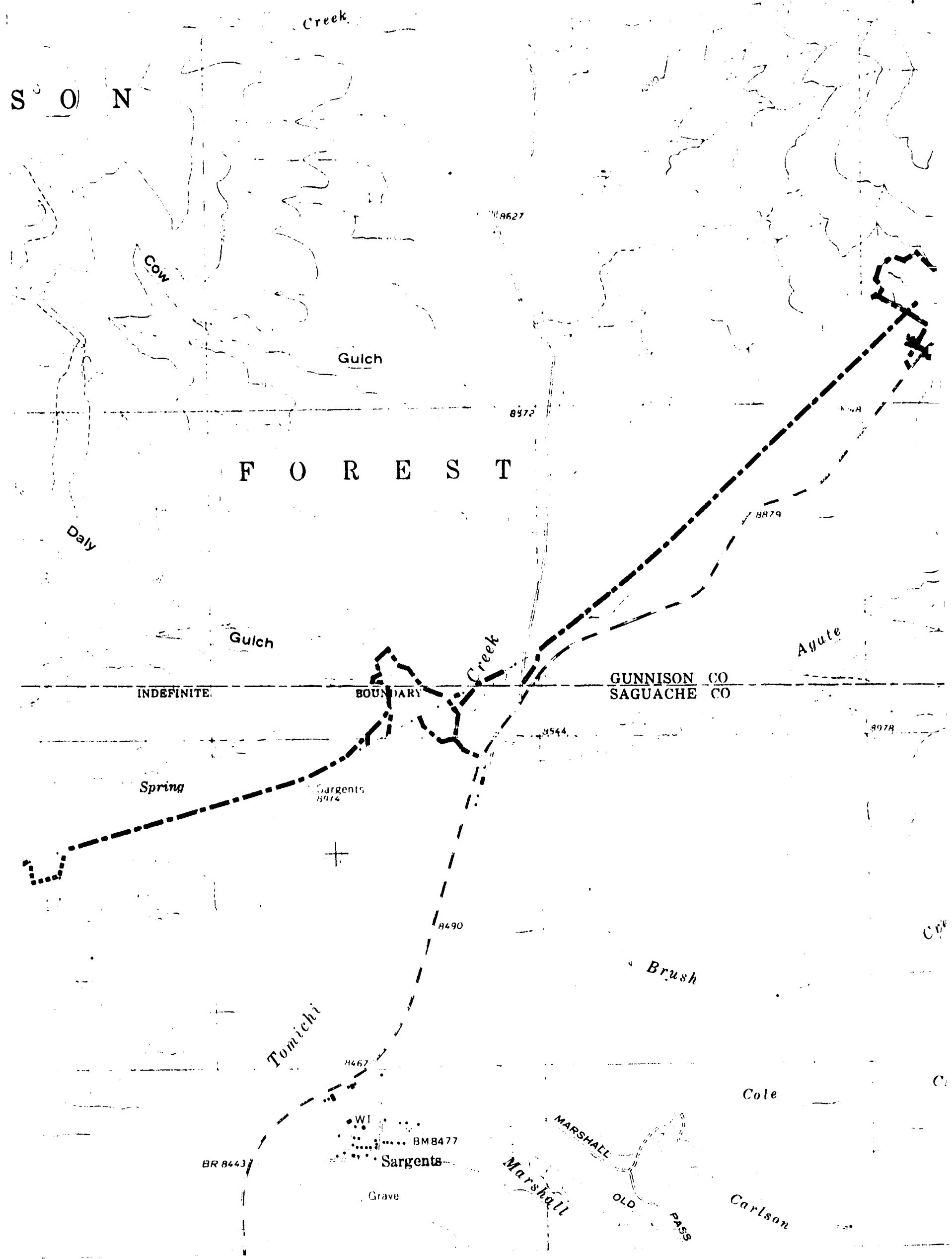




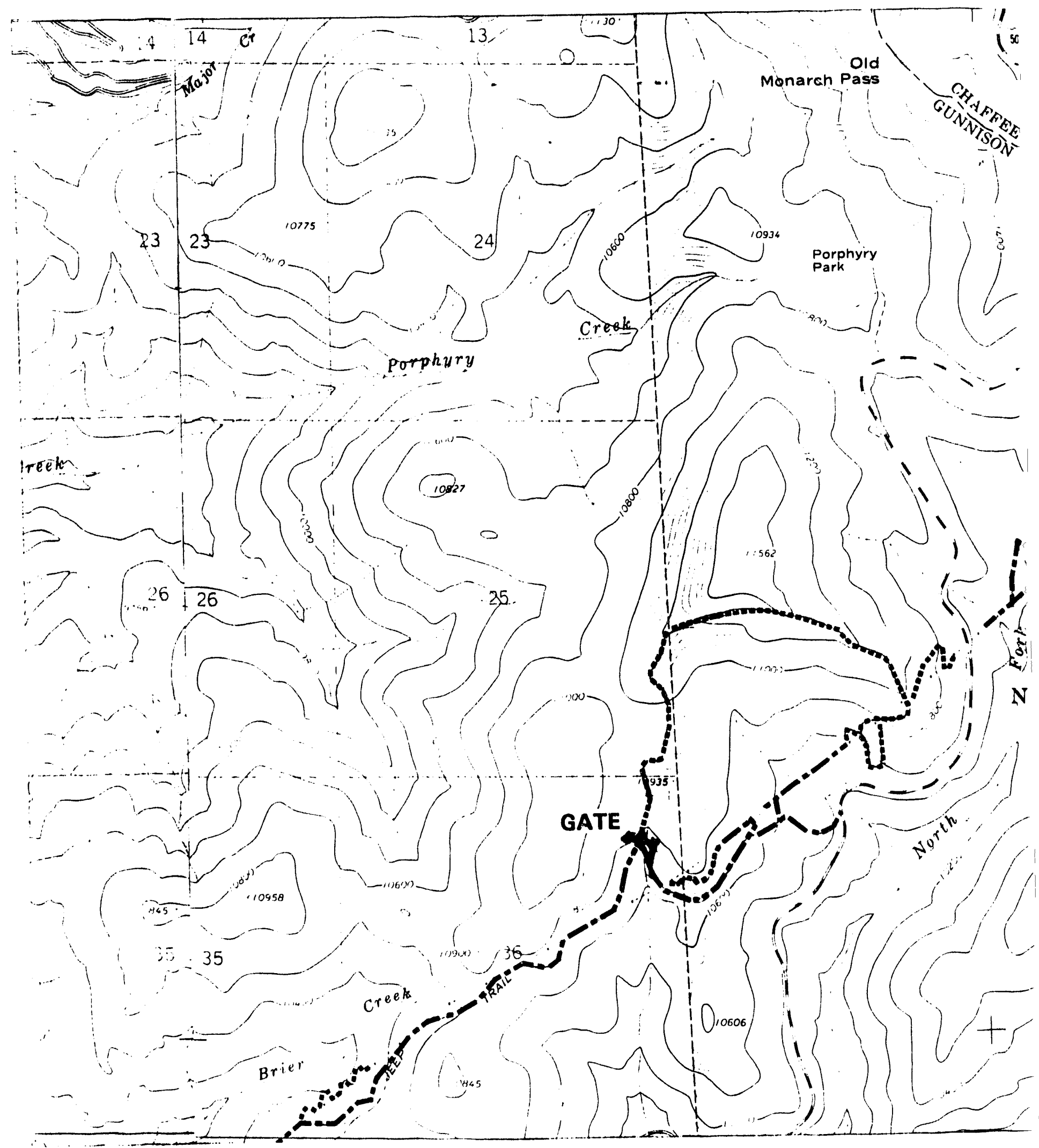


Also, to control public access on certain of Western's acce'ss roads, gates, or other means of traffic control would be installed. The locations and types of traffic controls would be identified in consultatior: with the appropriate land management agencies. Western and the USFS have determined the potential locations for some gates on Gunnisr, n National Forest. The approximate locations of those gates are illustrated on Figures 4 a-c.

Outside of Gunnison National Forest, new road construction is proposed at three locations. In Section 15, T49N, R2W, in Gunnison County, Western proposes to reroute a portion of an existing access road where the radius of a turn is too short. The location of the proposed relocation is indicated in Figure 5. In Section 12, T49N, R2W, in Gunnison County, BLM rerouted a portion of one of their roads and closed off a section of Western's access. In order to reestablish access Western proposes to construct about 1,900 feet of new access road. as shown on Figure 5. About 300 feet of new access road is proposed to be constructed approximately 2 miles northwest of the cown of Maysville on San Isabel National Forest, as shown on Figure 6. 


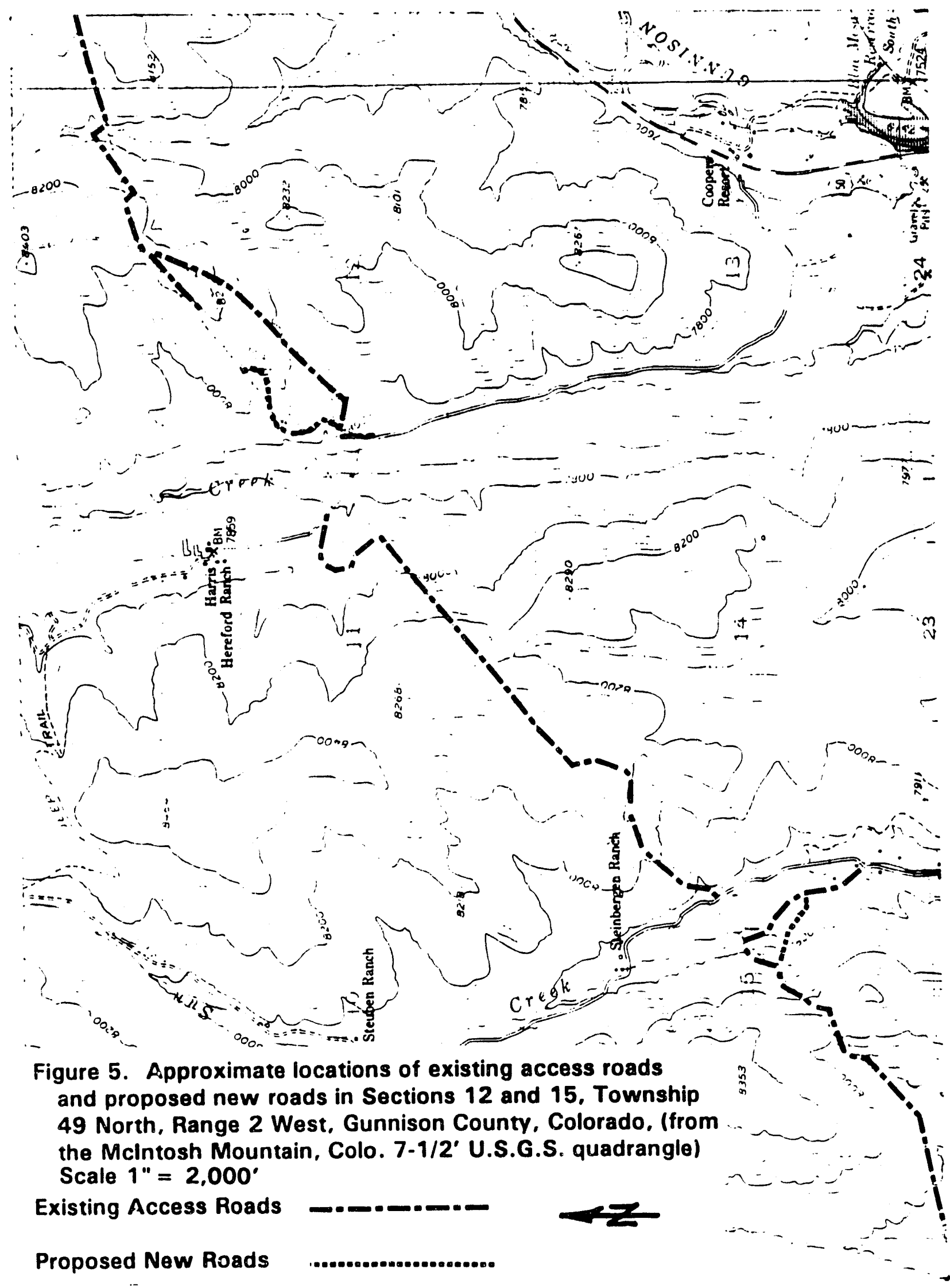




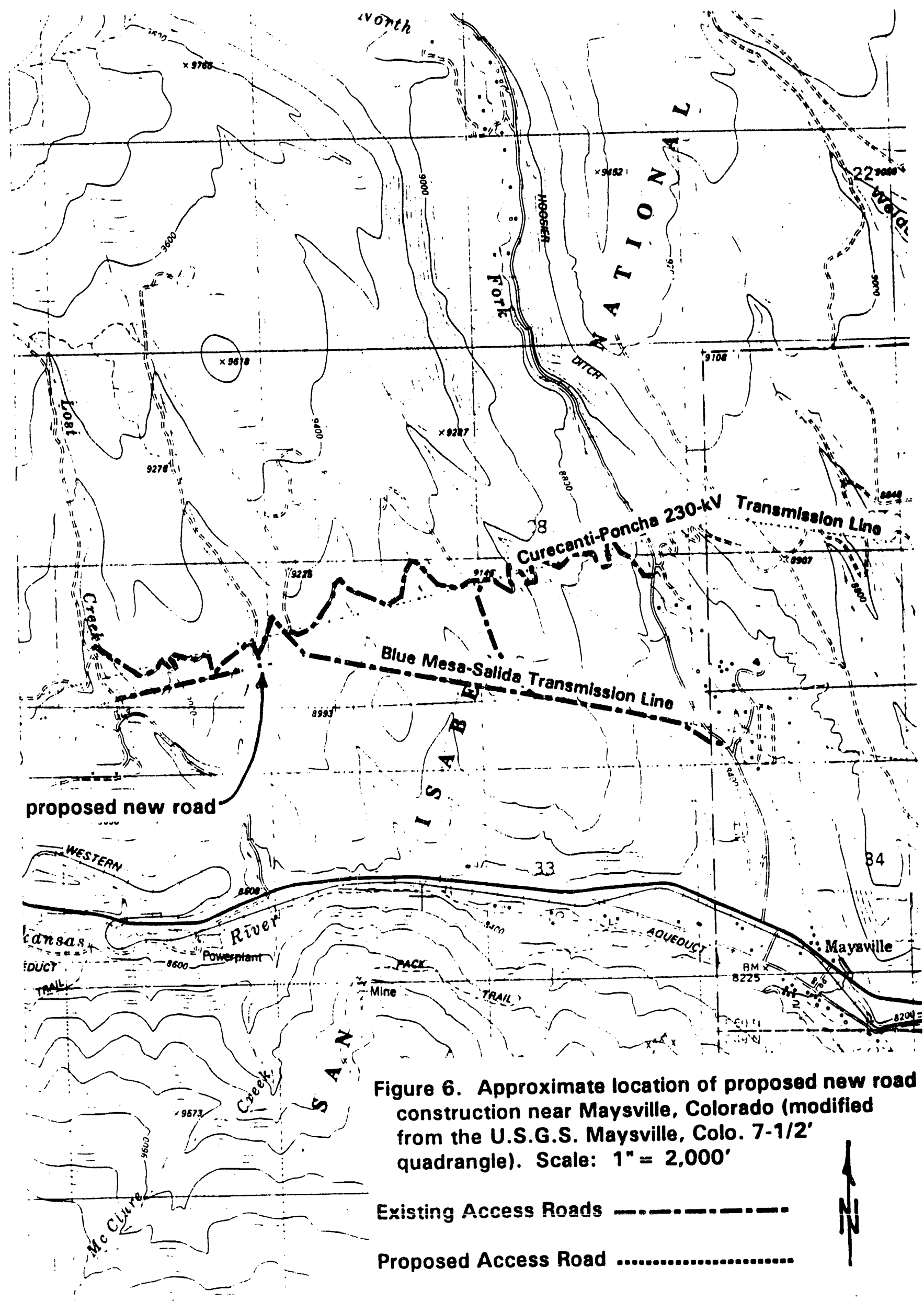




\section{B. Alternatives to Proposed Action}

\section{Helicopter}

In order to preclude the need for the proposed access road project, Western could use a helicopter to access its transmission lines. There are several drawbacks to using a helicopter for transmission line maintenance. First, there are no suitable landing sites along significant stretches of the lines. This would require the line crews to walk long distances carrying their tools, including hot sticks. Transporting tools and equipment by hand presents problems inasmuch as the hot sticks are susceptible to damage, and the other tools and equipment are both heavy and awkward. This raises safety concerns in that the lineman would be fatigued prior to beginning work on a particular structure, or equipment may be damaged or lost. Further, there are times when a ground vehicle must access the structures, such as an auger for a pole change out. Due to the elevation of the transmission line, particularly in the area of Monarch Pass, it is likely that a helicopter could not properly operate to service the line. Even where a helicopter could operate, for many kinds of activities, Western's helicopter would not be adequate, thus requiring contracting of a larger aircraft. Such a contract would be quite expensive and the costs would be passed on to Western's customers. In addition, using a helicopter to access the transmission line for maintenance activities, other than aerial patrol, would 
produce significant, albeit short-term, noise impacts which would be disturbing to wildlife and local residents.

\section{All Terrain Vehicles}

All terrain vehicles (ATVs) are a possible alternative to accessing the transmission line with conventional vehicles. However, ATVs are only able to transport one person with some tools. Western's requirements include the ability to transport such items as hot stick trailers, insulator strings, crossarms, wooden poles up to 90 feet long and weighing over 5,000 pounds, and the equipment to handle the poles.

\section{No action}

The no action alternative would consist of conducting maintenance in a normal fashion and not performing the necessary access roads maintenance or constructing new roads. In that case, gaining access to certain portions of the transmission lines would be impossible witil Western's usual maintenance vehicles. It would then be necessary to use extraordinary means to get to those portions of the lines, such as pulling trucks, cranes, manlift equipment, wood poles, etc., overland using a bulldozer or other tracked vehicle. When compared to the proposed action, this alternative would likely result in an increased level of soil erosion and greater disturbance to wildlife and their habitat. 


\section{Existing Environment}

\section{A. Vegetation}

The Draft Resource Management Plan and Environmental Impact Statement for the Gunnison Resource Area, BLM (U.S. Department of Interior 1991), and the Land and Resource Management Plan for the Grand Mesa, Uncompalgre and Gunnison National Forests (U.S. Department of Agriculture $1987)$ describe vegetation types in the Gunnison Basin, most of which are crossed by the Curecanti-Blue Mesa-Salida transmission lines. Those vegetation types occurring near the transmission lines include sagebrush/ mixed mountain shrub, ponderosa pine-douglas fir, lodgepole pine, aspen, blue spruce, spruce-fir, grassland, meadow, and riparian.

\section{B. Wildlife}

The area crossed by the transmission lines provides habitat to a large number of species of wildlife. Animals which may inhabit various parts of the project area include mammals such as elk (Cervus elaphus), muledeer (Odocoileus hemionus), bighorn sheep (Ovis canadensis), pronghorn antelope (Antilocapra americana), black bear (Ursus americanus), snowshoe hare (Lepus americanus), Nuttall's cottontail rabbit (Sylvilagus nuttalli), white-tailed jackrabbit (Lepus townsendii), coyote (Canis latrans), beaver (Castor canadensis), muskrat (Ondatra zibethica), bobcat (Lynx rufus), porcupine (Erethizon dorsatum), badger (Taxidea taxus), long-tailed weasel 
(Mustela frenata), pine martin (Martes americanus), red squirrel

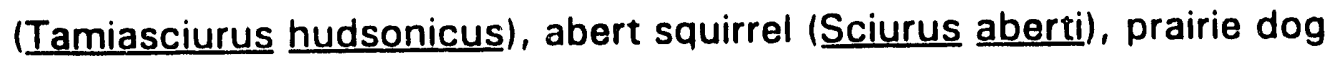
(Cynomys sp.), and yellow-bellied marmot (Marmota flaviventris); various amphibians and reptiles such as tiger salamander (Ambystoma tigrinum), chorus frog (Pseudacris triseriata), leopard frog (Rana pipiens), western terrestrial garter snake (Thamnophis elegans), and gopher snake (Pituophis melanoleucus); and birds such as blue grouse (Dendragrapus obscurus), sage grouse (Centrocercus urophasianus), mourning dove (Zenaidura macroura), various species of waterfowl including mallard (Anas platyrhynchos), blue-winged teal (Anas discors), green-winged teal (Anas crecca), American widgeon (Anas americana), northern shoveler (Anas clypeata), common snipe (Clapella gallinago), goshawk (Accipiter gentilis), and other raptors IU.S. Department of Agriculture 1979 and 1987, U.S. Department of Interior 1991).

Between Gunnison and Sargents, the Blue Mesa-Salida 115-kV transmission line crosses critical winter range for mule deer. According to the Colorado Division of Wildlife, some of the plant species critical to the wintering deer herd are bitterbrush, serviceberry, mountain mahogany, and rabbitbrush. The Colorado Division of Wildlife expressed concern for the condition of mule deer winter range. In recent decades, the shrub species critical to the deer have declined, resulting in a loss of vigor in the deer herd in the area. 


\section{Wetlands and Floodplains}

There are some sizable wetlands in the proposed project area, particularly along Tomichi Creek. There are also wetland areas in other areas, such as near Monarch Pass, between Highway 50 and the Continental Divide along the upper reaches of the Agate Creek drainage. In general, the wetlands are vegetated by herbaceous plants such as certain grasses, sedges (Carex sp.), rushes (Scirpus sp.), wiregrass (Juncus sp.), and iris (Iris missouriensis), which are dependent upon hydric soils. These wetlands are usually part of the floodplains of their associated creeks and may be considered riparian habitats. In other areas riparian vegetation associated with creeks, rivers and other surface waters is woody and consists of such

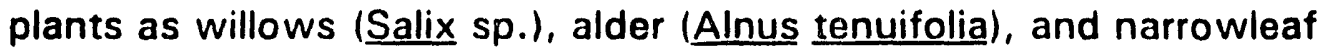
cottonwood (Populus angustifolia). The transmission lines and associated existing access roads cross a number of these wetland areas and floodplains.

\section{Special Status Plant or Animal Species}

The U.S. Fish and Wildlife Service advised Western that there are no species federally proposed or listed as threatened or endangered that would be expected to occur in the proposed project area. They did indicate that one plant species, skiff milkvetch (Astragalus microcymbus), is a candidate for listing. Skiff milkvetch occurs near Gunnison, Colorado in open sage- 
brush parks, often associated with yucca, prickly pear cactus, rabbitbrush, and occasionally juniper, on the Parlin-Lucky-Hopkins soil association.

\section{E. Cultural Resources}

The existing cultural resource data base for the study area is limited because most of the existing data base is derived from cultural resource management studies related to various development projects, which provide incomplete coverage of the area. Very little of the region surrounding the project area has been systematically surveyed for cultural resources. Cultural resources may include both prehistoric and historic artifacts of man's use of a site or area.

\section{Prehistoric Resources}

The prehistoric occupation in the study area includes four cultural stages: Paleoindian, Archaic, Formative, and Protohistoric (Sucec 1992, Kane 1990).

The Paleoindian stage $(10,000$ to 5,500 B.C. $)$ is representative of a series of terminal Pleistocene lifeways, all of which possess as their most distinctive feature the seasonally oriented procurement of various large mammals, such as mammoth. This stage is characterized by two major types of stone tool technology: (1) unspecialized core and flake production technique, primarily using percussion, and (2) blade technology with specialized fluted and unfluted lanceolate projectile points (Willey and 
Phillips 1958 in U.S. Department of Energy 1988). Due to the presence of remnant glaciers, it is unlikely that Paleoindian aboriginals used the high mountain areas (Kane 1990); however, sites from this stage, as well as Pleistocene fauna, have been recorded in the Gunnison River drainage (Stiger 1981 in Sucec 1992).

Following the disappearance of large game with the post-ice age warming trend, usually dated about 5,500 B.C. (Sucec, 1992), remains of the Archaic stage begin to occur. The Archaic stage ended about 500 A.D. Archaic subsistence relied on a hunting and gathering lifestyle, with exploitation of seasonally available resources over a large territory. Remains of the Archaic stage include large stemmed or stemmed indented base points, large side- and corner-notched projectile point forms, and a diverse tool assemblage including grinding slabs and handstones (Sucec 1992). Archaic groups used high altitude camps near the Continental Divide and alpine areas in other major mountain ranges during periods of warm climate (Kane 1990). Archaic campsites have been recorded in the vicinity of Monarch Pass, and the Monarch Game Drive was first constructed and used during this period (Kane 1990).

A Formative stage, characterized by the presence of horticulture and adoption of a sedentary or semi-sedentary lifestyle, was unlikely to have existed in the Rocky Mountain region (Guthrie, et al 1984 in Sucec 1992). This was probably due to the unsuitability of the higher elevations for 
agriculture because of the short growing season and severe winters. Evidence does exist that Formative stage people like the Fremont, Anasazi, and Woodland Tradition used certain areas of the mountain region for procurement of resources (Sucec 1992).

The period between about A.D. 1200 to 1880 is known as the Protohistoric/Historic stage (Sucec 1992, and U.S. Department of Energy 1988). The Protohistoric stage is characterized by a return to a subsistence pattern heavily dependent on seasonal movement to obtain available resources, a pattern previously associated with the Archaic stage. This stage is associated with the arrival of Numic speakers, who are presumed to be the ancestors of the Utes and Shoshones. New cultural and social patterns emerged with the advent of European contact and the acquisition of horses and firearms. By the time Euro-American explorers, traders, and trappers entered the region in the early nineteenth century, Utes and Shoshones were mounted societies, wealthier, and capable of long distance travel. Aggressive interaction between these aboriginals and increasing numbers of Anglos intensified throughout the nineteenth century, culminating in the expulsion of the Ute from the region in the 1880s (Reed 1984 in Sucec 1992). 


\section{Historic Resources}

Mehl (1984) provides the following overview of the Euro-American Period, as summarized by Sucec (1992):

The first Europeans to enter western Colorado in the 1770 s were Spanish explorers. In the 1820s fur trappers began to exploit the resources of the Southern Rocky Mountains.

Overtrapping and falling fur prices saw the demise of this industry. Euro-American use of the region was negligible until the discovery of gold in Colorado in 1859. A veritable gold rush followed the discovery, bringing thousands of EuroAmericans to western Colorado. As the precious metal industry spread across the Rocky Mountains, the 1870 s also saw the cattle industry gain prominence in the region. Mining continued to be economically important into the twentieth century. The lumber industry grew to support mining and the railroad network. Homesteaders moved steadily into the region, and transportation routes continued to develop. Although mining has declined, cattle ranching has remained an important industry into the present. More recently, the recreation and tourism industry has provided a boost to the economy of the region. 


\section{F. Visual Resources}

BLM inventoried and classified the scenery and landscapes on public land in the Gunnison Basin (U.S. Department of Interior 1991). According to that study, the supply of quality visual resources in the area is high compared to other BLM planning areas and moderate when compared with adjacent lands administered by the USFS. The report indicated that the demand for undisturbed or minimally disturbed visual resources in the area is moderate to high.

\section{G. Land Use}

Most of the proposed project area is in undeveloped rangeland, pasture land, and forest. There are some cultivated lands, with hay being the primary crop, included in the project area. About 10 miles of the transmission line crosses CNRA. The transmission line also passes through some residential areas in the vicinity of Gunnison, Colorado. Most of the transmission line crosses public lands administered by the BLM or USFS.

On BLM and USFS lands, there are a number of private users who hold grazing permits. In the vicinity of Sargents, Colorado, the private landowners and public lands permitees also provide hunting opportunities on their lands. Because of the impacts created by unauthorized entry and offroad vehicle use, public access is a major concern for private landowners and federal land managers. 


\section{Environmental Consequences}

The environmental consequences of the proposed project would be minimal. Throughout most of the length of the transmission lines all of the access roads already exist and have been used for $28-40$ years. Almost all of the proposed maintenance activities would be confined to the existing developed roadway. Where it would be necessary for maintenance activities to extend beyond the developed roadway, the amount of impact to presently undeveloped land would be slight. Maintenance activities that could affect presently undeveloped land include construction of $V$-ditches, installation of culverts, and riprapping culvert openings. None of these activities would extend more than a few feet beyond the edge of the roadway.

The proposed construction of new roads on Gunnison National Forest, the reroute of an access road in Section 15, T49N, R2W, near the Lake City turnoff of U.S. Highway 50, the 300 feet of new road that would be constructed on San Isabel National Forest, and 1,900 feet of new road near Beaver Creek would create very localized minor impacts to vegetation, wildlife habitat, visual resources, and possibly cultural resources.

\section{A. Impacts to Vegetation}

Where work would be performed on existing roads, there would be very slight impacts to vegetation. Unless there is significant rutting or other road surface damage, Western would not disturb herbaceous plants 
growing in the roads. There may be some vegetation damaged or destroyed along the edges of the roads in some locations, but those kinds of impacts would be minimized. Based on the nature and amount of work that would be performed and a knowledge of the approximate off-road area that would be disturbed, it is estimated that less than one acre of vegetation would be :yst along the existing roads.

New road construction would destroy all of the vegetation within the road prism. The road prism is the area from the top of the road cut to the toe of the fill slope on the downhill side; or all of the area occupied by the road. Assuming an average road prism width of 20 feet, the total amount of vegetated land surface affected by new road construction for the project would be about 7.25 acres in woodlands and about 6.02 acres in sagebrush/mountain shrub vegetation types. Trees cut as a result of road construction would be disposed in accordance with land owner/manager desires. They could be windrowed, cut into short lengths and stacked, hauled to an approved land fill, or otherwise disposed.

Noxious weed growth in disturbed areas could be an unacceptable consequence of the proposed work. In order to minimize noxious weed invasion and growth, Western would consult with land management agencies and county weed control offices to determine the need for and likely success of reclaiming disturbed soils with appropriate desirable plant species. 


\section{B. Impacts to Wildlife}

There would be no significant direct impacts to wildlife from the proposed project. Noise and the presence of humans and vehicles in the area may cause wildlife to move to more secluded areas, but only for the duration of the disturbance. All of the work activities would be very short-term; in the range of about 1-3 hours for each one. After a particular piece of work would be completed, the crews would move on, so impacts would be transitory and very localized. Western will consult with the Colorado Division of Wildlife to coordinate project activities to avoid unnecessary disturbance in areas and at times critical to the life cycles of elk, deer, and other sensitive wildlife.

Wildlife impacts would also be indirect through loss of habitat. The most critical wildlife habitat in the project area is winter deer and elk range. It is estimated that in the area between Gunnison and Sargents no more than 5 acres of shrubland habitat land would be disturbed by the proposed project. Not all of that land would contain plant species that are used by deer and elk. Therefore, the total loss of winter deer and elk habitat from the proposed project would be insignificant. Western will consult with the land management agencies and the Colorado Division of Wildlife to determine areas that could be successfully reclaimed with plant species used by wintering elk and deer. Where it is feasible, reclamation would virtually eliminate impacts to winter habitat. 
Although no transmission line construction is included as part of the proposed project, both Colorado Division of Wildlife and U.S. Fish and Wildlife Service expressed concern for bird electrocutions caused by the transmission lines. Large birds may be electrocuted on electrical distribution/transmission lines when they contact two conductors or a conductor and a grounded portion of the line. Such incidents most often occur on lower voltage lines where the spacing between conductors and conductors and grounds is closer than the wingspan of the birds (Olendorff, Miller, and Lehman, 1981). The wingspan of golden eagles, the largest birds that would be expected to frequent the project area, is less than 7 feet. The spacing between conductors and grounds on the transmission lines are about 10 feet and conductor-to-conductor spacing is about 12 feet. It would be nearly impossible for a bird to be electrocuted on the $115-k V$ transmission lines involved in this project.

In order to reduce disturbance to stream banks and bottoms and avoid future erosion or release of sediments that could impact fish spawning habitat, Western would consult with the U.S. Fish and Wildlife Service and Colorado Division of Wildlife to determine the most appropriate times to perform the proposed maintenance and construction activities. In addition, Western would review the proposed work items and ascertain if any activities could affect surface waterbodies and avoid such work to the extent possible. 


\section{Impacts to Wetlands and Floodplains}

The transmission lines cross a number of floodplains and a few wetland areas. Most of the wetlands are associated with Tomichi and Agate Creeks, between Gunnison and Monarch Pass. No new roads are proposed in wetlands or floodplains. In wetland and floodplain areas, all activities would be confined to the existing roadway and no fill material would be deposited. Vegetation in these areas would be treated with care in order to minimize damage. Impacts to floodplains and wetlands would be insignificant.

\section{Impacts to Special Status Plant or Animal Species}

There are no federally listed threatened or endangered species in the project area. Therefore the project would not impact such species. There is one candidate species for listing, skiff milkvetch, that may occur in the project area. A population of the species occurred near the project area at least $1 / 4$ mile away from the transmission line and any access roads but is presently considered extirpated (Heil and Porter (1990). Extant populations of the species are located south of the project area, the closest being more than 2 miles away (Heil and Porter (1990). In addition, the proposed work would be in the area of the existing road beds or immediately adjacent thereto and it is doubtful any skiff milkvetch plants would be affected by the project. According to Heil and Porter (1990), skiff milkvetch occurs mostly in undisturbed areas, associated with climax vegetation; however. 
occasionally it can also be found in recently disturbed sites. Sites with continual or reoccurring disturbance, such as roadsides, would not likely allow the species to maintain a stable population. Western would survey areas of potential skiff milkvetch habitat to determine the presence of the plant within the impact zone of the proposed project. If skiff milkvetch, or any other sensitive species were encountered during implementation of the proposed project, Western would suspend activities that could affect the species and consult with U.S. Fish and Wildlife Service to determine what measures, if any, could be taken to avoid adverse impacts to the species. Therefore, the proposed project would not affect special status plant or animal species.

\section{E. Impacts to Cultural Resources}

Western is consulting with the Colorado State Historic Preservation Officer (SHPO) for the proposed project, in accordance with Section 106 of the National Historic Preservation Act. In addition, land management agencies affected by the project are being consulted to ensure that cultural resources receive appropriate consideration in project planning. On the Gunnison National Forest, Western conducted cultural resources surveys on all of the existing and proposed new access roads that had not been previously surveyed and no significant sites were found. In other areas, pursuant to SHPO recommendations, prior to performing any of the proposed work, 
Western would conduct cultural resources surveys of all areas where work would be performed.

Western's preference is to avoid significant cultural resources, if possible. If it is not possible to avoid affecting a significant cultural resource site, Western would consult with the SHPO, Advisory Council on Historic Preservation, and affected land management agency, if any, to determine appropriate mitigation measures. Because of the kinds of sites that are expected to be found, the most likely mitigation for effects on significant sites would be data recovery. Through the use of avoidance and mitigation, the proposed project would not be expected to have any impacts on significant cultural resources.

\section{F. Impacts to Visual Resources}

Except the new road construction described earlier, all of the work would be performed on existing roads. The maintenance activities on existing roads would not significantly affect visual resources.

The proposed new access on Gunnison and San Isabel National Forests and near the Lake City turnoff could add an increment of new visual impacts on the viewshed. U.S. Highway 50 is the major thoroughfare in the project area. In the area of Gunnison National Forest, there are no formal viewpoints that overlook the transmission line. The viewpoint that most people would use is Highway 50, which is situated downhill from the transmission 
line. In addition, much of the transmission line is screened from view from the highway by intervening terrain and/or vegetation. Where new roads would be visible from the highway, they would be viewed only briefly and from below, which would tend to soften the visual impact. Neither the new road near Maysville nor the one near the Lake City turnoff would be visible from Highway 50.

There are a few private residences and commercial establishments along the southern side of Highway 50 that have views toward the transmission line. Those residences are all located between the western boundary of Gunnison National Forest and the Tomichi Creek Road, about 1 mile north of Sargents. The residences are situated at lower elevations than the transmission line and there is a significant amount of screening terrain. In the areas that could be viewed by the residences or customers of commercial establishments, the proposed new roads would be short and connected to existing roads. The new roads would not create a significant new visual impact for residents and/or customers in the project area.

\section{G. Impacts to Land Use}

Work on the existing access roads would have no effect on existing land uses. Because Western has rights of access to its transmission line, even without the proposed maintenance project, the very existence of the transmission line and access roads has an effect on future development or changes in land uses. 
The proposed new access roads would have minor effects on existing land uses. Some harvestable timber and cattle/wildlife forage may be lost but otherwise such present uses of the project area would not be affected. Therefore, the project would have minor impacts on existing land uses. Unauthorized public access to private and public lands is a concern to Western as well as land owners and managers. Public access to any portion of Western's transmission line rights-of-way presents the potential for vandalism and sometimes severe damage to facilities and possible harm to those accessing the transmission line without authorization. Western is consulting with CNRA, BLM, USFS, and private landowners to identify problem areas and feasible means to prevent or reduce unauthorized access.

Restricting public access to some of Western's access roads and abandoning unnecessary access roads would have a number of positive effects. Operation and maintenance of a transmission line may be adversely affected by unwitting or hostile acts by the public. Oftentimes transmission line insulators and/or conductors are shot-up, or sometimes nuts bolts, screws, and/or turnbuckles are loosened or removed, all of which may affect the structural integrity of the line and cause an outage. Restricting easy public access to the transmission line would reduce those kinds of incidents and save thousands of dollars in maintenance costs each year. Western's use of its access roads can be controlled to reduce or 
prevent impacts to wildlife and soil erosion. Public use, unless restricted by gates or other means, is not easily controlled, thereby providing much more opportunity for accelerated soil erosion and adverse impacts to wildlife such as disturbance or harassment.

\section{H. Other Potential Impacts}

It is not anticipated that any hazardous materials would be used in the proposed project. It is possible that diesel fuel, gasoline, or oil for the vehicles involved in the access road work could be spilled. If such an event were to occur, Western would follow approved procedures to prevent contamination of any area outside of the immediate spill area and would meet all appropriate standards applicable to clean the spill.

\section{Compliance With Other Environmental Regulations}

Western also considered the following resources and regulations and determined that they would not be significantly affected by the proposed project:

Fish and Wildlife Coordination Act. The proposed project would not significantly affect vegetation or nongame fish and wildlife.

Farmland Protection Policy Act. The proposed project would not affect farmland.

Recreational Resources. The proposed project would not affect a component of the National Wild and Scenic Rivers System or the 
National Trails System; a USFS roadless area or Wilderness Area; a BLM Wilderness Area or Area of Critical Environmental Concern; or other areas of ecological, scenic, or recreational importance.

\section{Additional Regulations Considered for the Proposal}

There would be no action required under the following statutes as a result of the proposed project:

Federal Water Pollution Control Act of 1972

Clean Water Act

Safe Drinking Water Act

Federal Land Policy and Management Act

Federal Insecticide, Fungicide and Rodenticide Act

Resource Conservation and Recovery Act

Toxic Substances Control Act

Comprehensive Environmental Response, Compensation and Liability Act of 1980

Superfund Amendments and Reauthorization Act of 1986

7. Agencies and Persons Consulted

Western consulted with the following agencies and individuals during project planning: 
U.S. Department of Agriculture

U.S. Forest Servic .

Grand Mesa, Uncompahgre, and Gunnison National Forests

Pike and San Isabel National Forests

U.S. Department of the Interior

Bureau of Land Management

Canon City District

Montrose District

U.S. Fish and Wildlife Service

National Park Service

Curecanti National Recreation Area

Colorado State Historic Preservation Officer

Colorado Division of Wildlife 


\section{REFERENCES}

Guthrie, Mark R., Powys Gadd, Renee Johnson, and Joseph Lischka. 1984. Colorado mountains prehistoric context. State Historical Society of Colorado, Denver.

Heil, Kenneth D. and J. Mark Porter. 1990. Status report for Astragalus microcymbus Barneby, Ms. on file, U.S. Fish and Wildlife Service, Grand Junction, Colorado.

Kane, Allen E. 1990. An overview of cultural resources on lands administered by the Pike and San Isabel National Forests, Cimarron and Comanche National Grasslands. U.S. Department of Agriculture, Forest Service, Pueblo, Colorado.

Mehls, Steven F. 1984. Colorado mountains historic context. State Historical Society of Colorado, Denver.

Olendorff, Richard R., A. Dean Miller, and Robert N. Lehman. 1981. Suggested practices for raptor protection on power lines: the state of the art in 1981. Raptor Research Foundation, St. Paul, Minnesota.

Reed, Alan D. 1984. West central Colorado prehistoric context. State Historical Society of Colorado, Denver.

Stiger, Mark. 1981. 1979 investigations at seven archaeological sites in the Curecanti National Recreation Area. Ms. on file, Midwest Archaeological Center, Lincoln, Nebraska.

Sucec, Rosemary J. 1991. Cultural resource inventory of Western Area Power Administration's Blue Mesa-Salida transmission line access roads Saguache and Gunnison Counties, Colorado, Cebolla Ranger District, Gunnison National Forest. Montrose, Colorado.

U.S. Department of Agriculture, Forest Service. 1979. Homestake Mining Company pitch project final environmental impact statement. Grand Mesa, Uncompahgre, and Gunnison National Forests, Delta, Colorado.

U.S. Department of Agriculture, Forest Service. 1987. Land and resource management plan Grand Mesa, Uncompahgre, and Gunnison National Forests. Delta, Colorado.

U.S. Department of Energy, Western Area Power Administration. 1988. Environmental assessment Craig-Bonanza 345-kV transmission line project. Salt Lake City, Utah. 
U.S. Department of the Interior, Bureau of Land Management. 1991. Draft Gunnison Resource Area resource management plan and environmental impact statement. Montrose, Colorado.

Willey, Gordon R. and Phillip Phillips. 1958. Methods and theory in American archaeology. University of Chicago Press, Chicago.

\section{EIS/GUNSALEA}



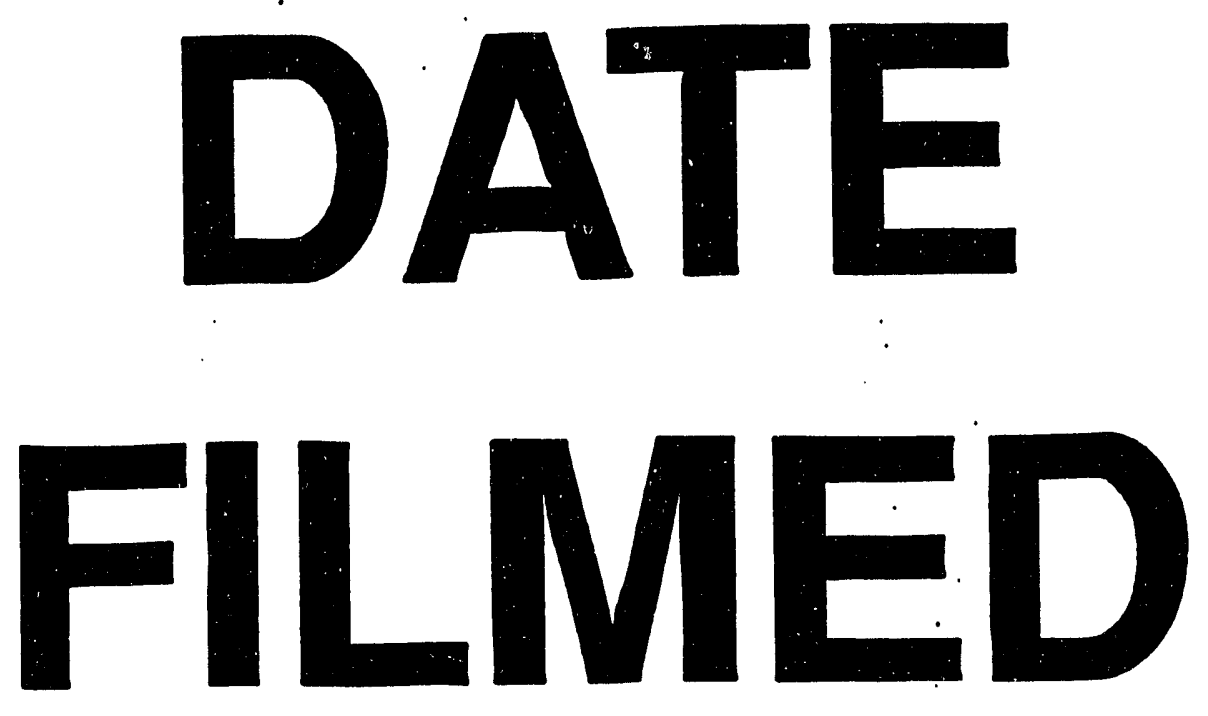

$10 / 19 / 93$
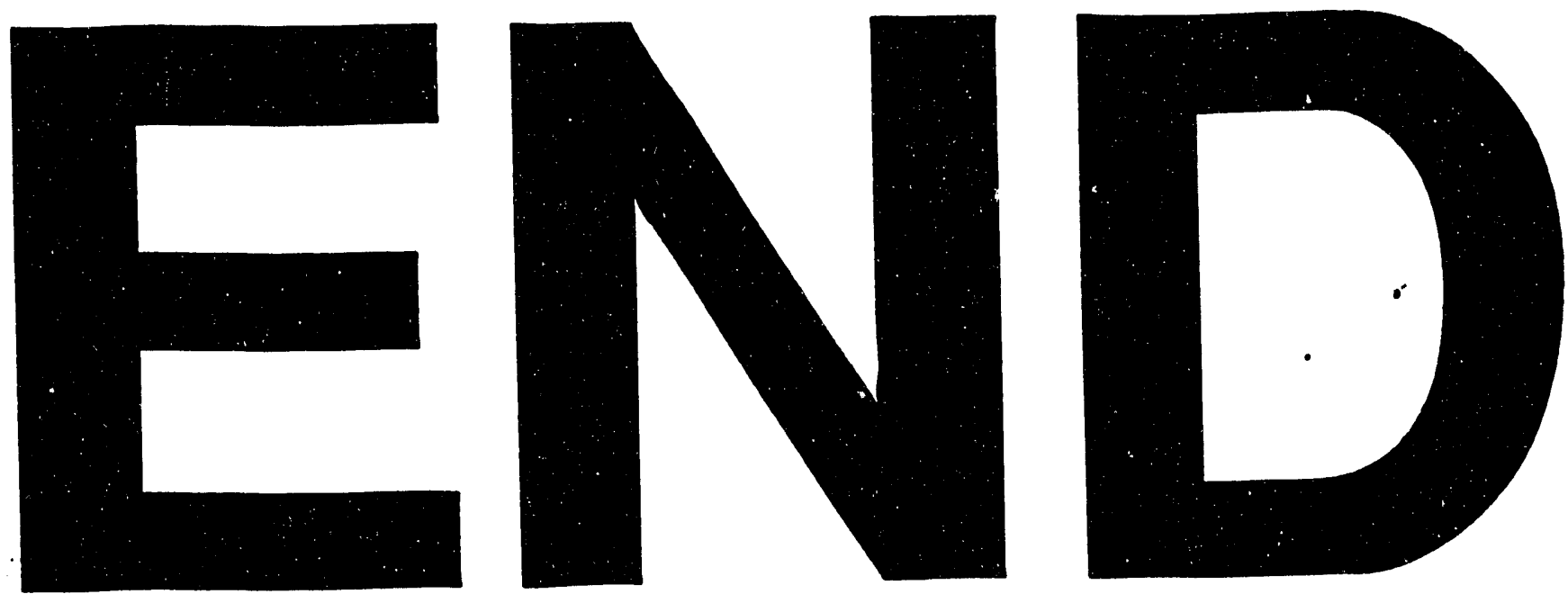